OPEN ACCESS

Edited by: Hemda Garelick,

Middlesex University London, United Kingdom

Reviewed by:

Ashok K. Chaturvedi, The University of Texas at

San Antonio, United States

Erin E. McClelland,

Independent Researcher,

Murfreesboro, United States

*Correspondence:

Karen L. Lang

karenluise@gmail.com

tThese authors have contributed equally to this work

Specialty section: This article was submitted to Antimicrobials, Resistance and Chemotherapy,

a section of the journal

Frontiers in Microbiology

Received: 15 July 2019 Accepted: 24 December 2019 Published: 06 February 2020

Citation:

Folly MLC, Ferreira GF, Salvador MR, Sathler AA, da Silva GF, Santos JCB, dos Santos JRA, Nunes Neto WR, Rodrigues JFS, Fernandes ES, da Silva LCN, de Freitas GJC, Denadai ÂM, Rodrigues IV, Mendonça LM,

Monteiro AS, Santos DA, Cabrera GM, Siless $G$ and Lang KL (2020) Evaluation of in vitro Antifungal Activity of Xylosma prockia (Turcz.) Turcz. (Salicaceae) Leaves Against Cryptococcus spp.

Front. Microbiol. 10:3114. doi: 10.3389/fmicb.2019.03114

\section{Evaluation of in vitro Antifungal Activity of Xylosma prockia (Turcz.) Turcz. (Salicaceae) Leaves Against Cryptococcus spp.}

Mariany L. C. Folly ${ }^{1+}$, Gabriella F. Ferreira ${ }^{1,2 t}$, Maiara R. Salvador', Ana A. Sathler2, Guilherme F. da Silva², Joice Castelo Branco Santos ${ }^{3}$, Julliana R. A. dos Santos ${ }^{3}$, Wallace Ribeiro Nunes $\mathrm{Neto}^{3}$, João Francisco Silva Rodrigues ${ }^{3}$, Elizabeth Soares Fernandes ${ }^{3}$, Luís Cláudio Nascimento da Silva ${ }^{3}$, Gustavo José Cota de Freitas ${ }^{4}$, Ângelo M. Denadai1,2, Ivanildes V. Rodrigues², Leonardo M. Mendonça ${ }^{2}$, Andrea Souza Monteiro ${ }^{3}$, Daniel Assis Santos ${ }^{4}$, Gabriela M. Cabrera ${ }^{5}$, Gastón Siless ${ }^{5}$ and Karen L. Lang ${ }^{1,2 *}$

${ }^{1}$ Multicentric Program in Biochemistry and Molecular Biology, Federal University of Juiz de Fora, Governador Valadares, Brazil, ${ }^{2}$ Department of Pharmacy, Federal University of Juiz de Fora, Governador Valadares, Brazil, ${ }^{3}$ Post Graduate Program, CEUMA University, São Luís, Brazil, ${ }^{4}$ Institute of Biological Sciences, Federal University of Minas Gerais, Belo Horizonte, Brazil, ${ }^{5}$ Department of Organic Chemistry, UMYMFOR-CONICET, FCEN, University of Buenos Aires, Buenos Aires, Argentina

Cryptococcus species are responsible for important systemic mycosis and are estimated to cause millions of new cases annually. The available therapy is limited due to the high toxicity and the increasing rates of yeast resistance to antifungal drugs. Popularly known as "sucará," Xylosma prockia (Turcz.) Turcz. (Salicaceae) is a native plant from Brazil with little information on its pharmacological potential. In this work, we evaluated in vitro anticryptococcal effects of the leaf ethanolic extract of $X$. prockia and its fractions against Cryptococcus gattii and Cryptococcus neoformans. We also evaluated phenotypic alterations caused by ethyl acetate fraction (EAF) (chosen according to its biological results). The liquid chromatography-mass spectrometry (LCMS) analysis of EAF demonstrated the presence of phenolic metabolites that belong to three structurally related groups as majority compounds: caffeoylquinic acid, coumaroylglucoside, and caffeoyl-glucoside/deoxyhexosyl-caffeoyl glucoside derivatives. The minimum inhibitory concentration (MIC) values against $C$. gattii and $C$. neoformans ranged from 8 to $64 \mathrm{mg} / \mathrm{L}$ and from 0.5 to $8 \mathrm{mg} / \mathrm{L}$, for ethanolic extract and EAF, respectively. The EAF triggered an oxidative burst and promoted lipid peroxidation. EAF also induced a reduction of ergosterol content in the pathogen cell membrane. These effects were not associated with alterations in the cell surface charge or in the thermodynamic fingerprint of the molecular interaction between EAF and the yeasts evaluated. Cytotoxic experiments with peripheral blood mononuclear cells (PBMCs) demonstrated that EAF was more selective for yeasts than was PBMCs. The results may provide evidence that $X$. prockia leaf extract might indeed be a potential source of antifungal agents.

Keywords: Cryptococcus spp., Xylosma prockia, antifungal agents, natural products, biodiversity 


\section{INTRODUCTION}

In recent years, the incidence of opportunistic mycosis has increased significantly, becoming an important public health problem (Herkert et al., 2017). Cryptococcosis is an important systemic mycosis caused by fungi of the genus Cryptococcus, mainly by Cryptococcus neoformans and Cryptococcus gattii, responsible for approximately one million new cases and 600,000 deaths annually (Maziarz and Perfect, 2016). Cryptococcal meningitis is the most severe form of the disease and remains a major problem in resource-limited countries, where HIV prevalence is high and access to healthcare is limited. Worldwide, nearly 220,000 new cases of cryptococcal meningitis occur each year, resulting in 181,000 deaths (Rajasingham et al., 2017). In this context, immunocompromised patients, such as the elderly and individuals with chronic pathologies, are at high risk of becoming ill with cryptococcosis (May et al., 2016).

The current therapeutic options for treating these mycoses are restricted due to the increased resistance of yeasts to the available drugs, as well as the high toxicity of some, such as amphotericin B (AMB) (Bongomin et al., 2018; Wiederhold, 2018).

Several strategies and techniques are currently available to assist in drug discovery and development, and natural products represent one of the most successful alternatives (Davison and Brimble, 2019). Different studies have investigated the activity and efficacy of plant extracts/fractions (Thammasit et al., 2018) and their secondary metabolites (Alves et al., 2017; Li et al., 2017) against Cryptococcus spp. These have indicated that plant-derived preparations and compounds act in such pathogens by targeting their survival and virulence, increasing host defense or enhancing the activity of known antifungal drugs. However, the antifungal potential of many plant species have not yet been evaluated.

Xylosma prockia (Turcz.) Turcz. (Salicaceae) is a native species from Brazil (found mainly in the northeast, southeast, and south), popularly known as "sucará" (Longhi et al., 2006). The few existing studies on this plant are restricted to its morphology and taxonomy and have not addressed its chemical constitution and pharmacological activities. Flavonoids, triterpenes, coumarins, and phenolic glycosides have been described in other species of the genus Xylosma (Parveen and Ghalib, 2012; Devi et al., 2013). In addition, reports have demonstrated antifungal, antibacterial, antispasmodic, narcotic, and sedative properties for extracts and compounds isolated from some Xylosma spp. (Mosaddik et al., 2004; Castro et al., 2008; Devi et al., 2013).

In this work, the antifungal activity of $X$. prockia leaf ethanolic extract (EE) and fractions was investigated for the first time against C. neoformans and C. gattii. The possible effects of $X$. prockia on the pathogen phenotype were also investigated.

\section{MATERIALS AND METHODS}

\section{Plant Material and Extraction}

The leaves of $X$. prockia (Turcz.) Turcz. (Salicaceae) were collected in Governador Valadares ( $\left.18^{\circ} 51^{\prime} 04^{\prime \prime} \mathrm{S}, 41^{\circ} 56^{\prime} 58^{\prime \prime} \mathrm{W}\right)$, Minas Gerais, Brazil, in December 2015. The sample was identified by the botanist Dr. Ronaldo Marquete and deposited in the RB Herbarium of Rio de Janeiro Botanical Garden, Rio de Janeiro, Brazil (voucher specimen number RB 773293), in August 2018. The research was authorized by the National System for the Management of Genetic Heritage and Associated Traditional Knowledge (SISGEN; no. A66F830).

The leaves were dried at $40^{\circ} \mathrm{C}$ in an air-circulating oven, and the powdered leaves $(340 \mathrm{~g})$ were extracted by maceration in $99.8 \%$ ethanol for 5 days (plant: solvent, 1:10, w/v; at room temperature). The organic solvent was evaporated under reduced pressure in a rotary evaporator (temperature below $\left.45^{\circ} \mathrm{C}\right)$ to obtain the EE $(68.2 \mathrm{~g}, 20.1 \%)$. Subsequently, the $\mathrm{EE}$ has undergone a sequential liquid-liquid extraction with organic solvents of increased polarity in the following order: $n$-hexane (HF, $14 \mathrm{~g}, 20.5 \%$ ), dichloromethane (DF, $3 \mathrm{~g}, 4.4 \%$ ), ethyl acetate (EAF, $8 \mathrm{~g}, 11.7 \%$ ), and $n$-butanol (BF, $6 \mathrm{~g}, 8.8 \%$ ).

\section{Liquid Chromatography-Mass Spectrometry (LC-MS) Analysis}

The LC-MS analyses were performed in an RRLC Agilent 1200 using a Luna $\mathrm{C}_{18}$ column $(3 \mu \mathrm{m}, 2.0 \times 100 \mathrm{~mm}$; Phenomenex, Torrance, CA, United States). The mobile phase consisted of $85 \%$ water containing $0.1 \%$ formic acid (A) and $15 \%$ acetonitrile (B). The flow rate was $0.3 \mathrm{ml} / \mathrm{min}$, and the column temperature was set to $30^{\circ} \mathrm{C}$. Detection was performed with a diode array detector (DAD) from 190 to $950 \mathrm{~nm}$ coupled to a mass spectrometer.

Mass spectrometric analyses were performed in a Bruker micrOTOF-Q II mass spectrometer (Bruker Daltonics, Billerica, MA, United States), equipped with an electrospray source using the negative mode. The instrument was operated at a capillary voltage of $4.5 \mathrm{kV}$ with an end-plate offset of $500 \mathrm{~V}$, dry temperature of $200^{\circ} \mathrm{C}$ using $\mathrm{N}_{2}$ as dry gas at $6.0 \mathrm{~L} / \mathrm{min}$, and a nebulizer pressure of 3.0 bars. Multipoint mass calibration was carried out using a sodium formate solution from m/z 50 to 1,200 in the negative ion mode. Data acquisition and processing were carried out using the software Bruker Compass Data Analysis version 4.3 supplied with the instrument.

\section{Cryptococcus Strains and Study Design}

We initially assessed the antifungal activity of $\mathrm{EE}$ and its fractions against two strains of C. gattii and two strains of C. neoformans. The ethyl acetate fraction (EAF) presented better antimicrobial activity and yield; therefore, it was chosen for this study.

For the "antifungal drug susceptibility testing" assays, we tested two reference strains of $C$. gattii [American Type Culture Collection (ATCC) 24065 and ATCC 32608] and four reference strains of C. neoformans (ATCC 24067, ATCC 28957, ATCC 62066, and ATCC H99), which were obtained from the Culture Collection of the University of Georgia (Atlanta, GA, United States). Seven clinical isolates of C. gattii, five clinical isolates of C. neoformans, and one environmental isolate of each species, all from the Culture Collection of the Mycology Laboratory/ICB-UFMG, were also used in this study (Magalhães et al., 2013). Isolates were maintained on Sabouraud dextrose broth (SDB) at $-80^{\circ} \mathrm{C}$. Prior to each test, the strains were subcultured on Sabouraud dextrose agar (SDA) for $48 \mathrm{~h}$ at $35^{\circ} \mathrm{C}$. 
The ATCC 32608 and L27/01 of C. gattii and ATCC 2895 and ATCC $\mathrm{H} 99$ of C. neoformans strains were randomly chosen for further experiments, except for ITC, in which we used ATCC 32068 and ATCC H99 strains.

\section{Antifungal Drug Susceptibility Testing}

The minimum inhibitory concentrations (MICs) for EE and its fractions were determined by the antifungal microdilution susceptibility standard test, proposed by the CLSI M27-A3 method (Institute Clinical and Laboratory Standards [CLSI], 2008). The inoculum was prepared in sterile saline, and the transmittance of suspensions was adjusted to $75-77 \%$ (530 nm), followed by further dilution in RPMI 1640 buffered with MOPS (Sigma-Aldrich ${ }^{\circledR}$ ) medium to achieve 1.0-5.0 $\times 10^{3}$ colony-forming unit $(\mathrm{CFU}) / \mathrm{ml}$. The final concentrations of $\mathrm{EE}$ and fractions ranged from 0.25 to $128 \mathrm{mg} / \mathrm{L}$, from 0.125 to $64 \mathrm{mg} / \mathrm{L}$ for fluconazole (FLC) (Sigma-Aldrich ${ }^{\circledR}$ ), and from 0.03 to $16 \mathrm{mg} / \mathrm{L}$ for AMB (Sigma-Aldrich ${ }^{\circledR}$ ). The plates were incubated at $35^{\circ} \mathrm{C}$ for $72 \mathrm{~h}$. The MIC was determined visually as $100 \%$ growth inhibition when compared to the control, except for FLC, in which the MIC was determined visually as 50\% growth inhibition, when compared to the control. The results were confirmed through the assessment of fungal metabolic activity by adding 3-(4,5-dimethylthiazol-2-yl)-2,5-diphenyl- $2 \mathrm{H}$ tetrazolium bromide (MTT) (Sigma-Aldrich $\left.{ }^{\circledR}\right)(5.0 \mathrm{mg} / \mathrm{ml})$. For this, the plates were incubated at $35^{\circ} \mathrm{C}$ for $3 \mathrm{~h}$, and DMSO was added before spectrophotometric reading at $570 \mathrm{~nm}$.

The minimal fungicidal concentration (MFC) was defined as the concentration of the antifungal agent in which the number of CFUs was zero. For determining the MFC, at the end of the MIC experiments, the samples $(10 \mu \mathrm{l})$ were removed from all wells of the standard MIC plates and placed on Petri plates containing SDA $\left(\right.$ Difco $\left.^{\circledR}\right)$. The plates were incubated for $72 \mathrm{~h}$ at $35^{\circ} \mathrm{C}$ before the colonies were counted. All tests were performed in duplicate and repeated three times.

\section{Time-Kill Curves}

An assay was performed to evaluate time-kill kinetics of EAF against C. gattii (ATCC 32068 and L27/01) and C. neoformans (ATCC 28957 and ATCC H99) strains as previously described by Ahmad et al. (2011), with modifications. A 100- $\mu$ l inoculum of yeasts $\left(1.0-5.0 \times 10^{3} \mathrm{CFU} / \mathrm{ml}\right)$ was placed on microtiter plates at different concentrations of EAF (MIC, $2 \times$ MIC, and $4 \times$ MIC) and incubated at $35^{\circ} \mathrm{C}$ for $72 \mathrm{~h}$. A control growth was performed at $0,3,6,12,24,36,48$, and $72 \mathrm{~h}$. Aliquots of $100 \mu \mathrm{l}$ were removed from each test and plated on SDA $\left(\mathrm{Difco}^{\circledR}\right)$. For control growth, the aliquots were diluted in saline solution prior to plating. Colony counts were determined after incubation at $35^{\circ} \mathrm{C}$ for $72 \mathrm{~h}$. The results were expressed as CFUs per milliliter.

\section{In vitro Interaction of FLC and AMB With EAF}

The possible interactions between $\operatorname{EAF}(0.25-128 \mathrm{mg} / \mathrm{L})$ and the commercially used antifungals FLC $(0.5-32 \mathrm{mg} / \mathrm{L})$ and AMB $(0.03$ to $1 \mathrm{mg} / \mathrm{L})$ were investigated in vitro by using a checkerboard microdilution assay, as previously described by Santos et al. (2012). The plates were incubated at $35^{\circ} \mathrm{C}$ for $72 \mathrm{~h}$, and the cellular metabolic activity was determined by the MTT salt.

The interactions were determined by the fractional inhibitory concentration index (FICI) (Odds, 2003). FICI was calculated as (MIC FLC or AMB in combination with EAF/MIC FLC or AMB alone) + (MIC EAF in combination with FLC or AMB/MIC EAF alone). Interactions were classified as synergism if FICI $\leq 0.5$, indifference if $0.5>$ FICI $\leq 4.0$, and antagonism if FICI $>4.0$. This assay was tested in duplicate and repeated twice.

\section{Measurement of Reactive Oxygen Species (ROS) Production}

The endogenous production of ROS and peroxynitrite by fungal cells was measured by fluorometry (Synergy 2 SL Luminescence Microplate Reader; BioTek $^{\circledR}$ ) with specific probes (Ferreira et al., 2013). The cells $\left(1.0 \times 10^{3}\right.$ to $5.0 \times 10^{3}$ cells per milliliter $)$ were incubated with EAF (MIC and $2 \times$ MIC) or AMB (MIC) in RPMI 1640 without phenol red (Sigma-Aldrich ${ }^{\circledR}$ ) containing $10 \mathrm{mM} \mathrm{2,7}$ '-dichlorofluorescein diacetate (for ROS quantification; Invitrogen $\left.{ }^{\circledast}\right)$ or $20 \mathrm{mM}$ dihydrorhodamine 123 (for peroxynitrite quantification; Sigma-Aldrich ${ }^{\circledR}$ ). The fluorescence was measured $24 \mathrm{~h}$ later at $500 \mathrm{~nm}$. At the end of the experiments, $10 \mu \mathrm{l}$ of each sample was placed on SDA-containing plates, and the numbers of CFU were counted. The results are expressed as arbitrary units of fluorescence/CFU.

\section{Measurement of Mitochondrial Membrane Potential}

The cells $\left(1 \times 10^{6}\right.$ cells per milliliter, in $\left.500 \mu \mathrm{l}\right)$ were treated with EAF (MIC) for $24 \mathrm{~h}$, at $37^{\circ} \mathrm{C}$. After being washed, the cell pellets were resuspended in phosphate-buffered saline (PBS) $(500 \mu \mathrm{l})$ and labeled with rhodamine 123 (Rho 123) $(10 \mu \mathrm{g} / \mathrm{ml}$ in the dark for $10 \mathrm{~min}$ ) (Ronot et al., 1986; Olsson et al., 1987; Alves et al., 2017). The cells were washed three times, resuspended in PBS, and analyzed by flow cytometry (BD Accuri ${ }^{\mathrm{TM}}$, United States; FL3 channel for AO and FL1 for Rho 123). A total of 10,000 events were analyzed for each sample. Changes in the fluorescent intensity of Rho 123 were quantified using the variation index (VI) obtained by the equation (MT - MC)/MC, in which MC is the mean of fluorescent intensity of control and MT is the mean of treated cells. The negative values of VI correspond to mitochondrial membrane depolarization.

\section{Lipid Peroxidation}

Thiobarbituric acid-reactive substances (TBARSs) were measured as an index of lipid peroxidation products, as previously described by Soares et al. (2011). C. neoformans and C. gattii were inoculated into $50 \mathrm{ml}$ of SDB overnight (Difco ${ }^{\circledR}$ ) containing EAF (MIC and $2 \times$ MIC) or hydrogen peroxide (HP) as a positive control. The cultures were incubated for $24 \mathrm{~h}$. After incubation, the tubes were centrifuged (Jouan, model BR4i) at $2,700 \mathrm{rpm}$ for $5 \mathrm{~min}$ at $4^{\circ} \mathrm{C}$, and the supernatant was discarded. The precipitates (cells) were washed with sterile distilled water, and their net wet weight was determined. The TBARS values were calculated using the extinction coefficient of $156 \mathrm{~L} / \mathrm{mol} \cdot \mathrm{cm}$. 
The results were divided by the net weight and expressed as nanomolars per gram.

\section{Ergosterol Quantification}

Total intracellular sterols were extracted as previously described, with modifications (Arthington-Skaggs et al., 1999; Alves et al., 2017). C. neoformans and C. gattii were inoculated into $50 \mathrm{ml}$ of SDB overnight $\left(\right.$ Difco $\left.^{\circledR}\right)$, containing MIC or $2 \times$ MIC of EAF or FLC (MIC) as a positive control. The cultures were incubated for $24 \mathrm{~h}$. After incubation, the tubes were centrifuged (Jouan, model BR4i) at 2,700 rpm for $5 \mathrm{~min}$ at $4^{\circ} \mathrm{C}$, and then the supernatant was removed. The cells were washed with sterile distilled water, and the net wet weight pellet was determined. Three milliliters of a $25 \%$ potassium hydroxide alcohol solution $(25 \mathrm{~g}$ of $\mathrm{KOH}$ in 65\% ethanol) was added to each pellet and mixed for $1 \mathrm{~min}$. Cell suspensions were transferred to sterile tubes and incubated at $85^{\circ} \mathrm{C}$ in a water bath for $1 \mathrm{~h}$. After incubation, the tubes were allowed to cool down to room temperature. The sterols were extracted by adding a mixture of $1 \mathrm{ml}$ of sterile distilled water and $3 \mathrm{~mL}$ of $n$-heptane followed by vigorous vortexing for $3 \mathrm{~min}$. The supernatant was removed, and the reading was performed in a spectrophotometer at 282 and $230 \mathrm{~nm}$. A calibration curve with standard ergosterol (Sigma-Aldrich ${ }^{\circledast}$ ) was used to calculate the quantity of ergosterol. In all cases, the absorbance of ergosterol was the result of the subtraction of the absorbance obtained at 282 and $230 \mathrm{~nm}$ (Breivik and Owades, 1957). The results were divided by net weight and expressed as $\mathrm{mg} / \mathrm{L} \cdot \mathrm{g}^{-1}$.

\section{Sorbitol Test}

The sorbitol protection assay was carried out by the modified CLSI M27-A3 protocol as described above (Lee and Kim, 2016). Briefly, one plate was prepared containing EAF ranging from 0.25 to $128 \mathrm{~mol} / \mathrm{L}$ and another plate containing EAF ranging from 0.25 to $128 \mathrm{~mol} / \mathrm{L}$ plus $0.8 \mathrm{M}$ of sorbitol as osmotic protectant. The plates were incubated at $35^{\circ} \mathrm{C}$ for $72 \mathrm{~h}$. The reading was performed visually. All tests were conducted in duplicates for each strain.

\section{Carboxyfluorescein Succinimidyl Ester (CFSE) Assay}

Cryptococcus gattii and C. neoformans were grown in RPMI supplemented with $0.5 \times$ MIC of EAF or with no drugs for $24 \mathrm{~h}$ at $37^{\circ} \mathrm{C}$, washed in PBS, and stained with $25 \mu \mathrm{g} / \mathrm{ml}$ CFSE (Sigma-Aldrich ${ }^{\circledR}$ ) for $30 \mathrm{~min}$ at $30^{\circ} \mathrm{C}$. The yeasts were washed in PBS containing $2 \%$ bovine serum albumin (BSA) to remove excessive CFSE. Stained yeast cells were passed through a 25G 7/8-in. needle to dissociate clumped cells. Flow acquisition was performed with a FACSCalibur flow cytometer (BectonDickinson ${ }^{\circledR}$ ), using the CellQuest software (Becton-Dickinson ${ }^{\circledR}$ ). A total of 10,000 events were analyzed for each sample. The results are expressed as arbitrary units of fluorescence.

\section{Cell Diameter, Capsule Size, and Zeta Potential (ZP) Measurements}

Yeasts cells cultured with $0.5 \times$ MIC of EAF were visualized with an optical microscope (Axioplan, Carl Zeiss ${ }^{\circledR}$ ) following suspension in India ink. The capsule and the diameter of at least 100 cells were measured using the ImageJ $1.40 \mathrm{~g}$ software $^{1}$ (National Institutes of Health, NIH, Bethesda, $M D$, United States). The surface-to-volume ratio $(S / V)$ was calculated using the formula $3 / r$, in which $r$ is the radius (Ferreira et al., 2015).

Zeta Potential experiments were performed using a Malvern Zetasizer Nano ZS equipment (Ferreira et al., 2016). The ZP was determined by a laser Doppler microelectrophoresis technique, at a scattering angle of $173^{\circ}$, using a disposable cell folded capillary (DPS1060). Zeta Plus software was used for ZP (Brookhaven Instruments Corp., Holtsville, NY, United States). ZP values were calculated as the average of 10 independent measurements, each obtained as the mean of 30 counts.

\section{Isothermal Titration Calorimetry (ITC)}

Isothermal Titration Calorimetry experiments were carried out with one repetition using a VP-ITC microcalorimeter (MicroCal, LLC, Northampton, MA, United States) at $25^{\circ} \mathrm{C}$, after previous electrical and chemical calibration (Monteiro et al., 2011). All the solutions employed in the experiment were previously degasified under vacuum (140 mbar) during $8 \mathrm{~min}$. Each titration experiment consisted of 51 successive injections of $5 \mu \mathrm{l}$ of EAF at $1,000 \mathrm{mg} / \mathrm{L}$ into a chamber containing $1.5 \mathrm{ml}$ of $C$. gattii and $C$. neoformans suspension at $1 \times 10^{6} \mathrm{CFU} / \mathrm{ml}$. The first $1-\mathrm{ml}$ injection was discarded to eliminate diffusion effects of the syringe material to the calorimetric chamber. The injection time was $2 \mathrm{~s}$, and the interval between the injections was $240 \mathrm{~s}$.

\section{Human PBMC Viability}

The MTT colorimetric assay, as proposed by Mosmann (1983), was used to determine the PBMC viability when grown with EAF. PBMCs were collected from eight healthy human volunteers (non-smoking donors who had not received any medication for the last 15 days prior to sampling, aged 1835 years old) who provided written formal consent. This study was approved by the Research Ethics Committee of the Federal University of Juiz de Fora (protocol number: 70972117.0.0000.5147). The cells were obtained by the standard method of density gradient centrifugation over Histopaque R1119 according to the manufacturer's instructions. PBMCs were suspended in a supplemented RPMI 1640 culture medium (Life Technologies ${ }^{\circledR}$ ) containing 10\% fetal bovine serum (Life Technologies $\left.^{\circledR}\right)$, streptomycin $\left(100 \mu \mathrm{g} / \mathrm{ml}\right.$; Sigma-Aldrich $\left.{ }^{\circledR}\right)$, and penicillin $\left(100 \mathrm{U} / \mathrm{ml}\right.$; Sigma-Aldrich $\left.{ }^{\circledast}\right)$.

In a 96-well plate, $100 \mu \mathrm{l}$ of PBMCs at a density of $1 \times 10^{6}$ cells per milliliter suspended in RPMI 1640 medium was added. After $24 \mathrm{~h}$ of incubation at $37^{\circ} \mathrm{C}$ in $\mathrm{CO}_{2}$, the cells were incubated with $100 \mu \mathrm{l}$ of different concentrations of EAF $(4-512 \mu \mathrm{g} / \mathrm{ml}$; in RPMI 1640 medium), in $\mathrm{CO}_{2}(5 \%)$, at $37^{\circ} \mathrm{C}$, for $24 \mathrm{~h}$. Then, $10 \mu \mathrm{l}$ of MTT solution $\left(5 \mathrm{mg} / \mathrm{ml}\right.$; Sigma-Aldrich $\left.{ }^{\circledast}\right)$ was added to all wells of the plate, which was incubated for $4 \mathrm{~h}$. After the incubation period, MTT medium was carefully removed from all wells, and $100 \mu \mathrm{l}$ of DMSO (Nuclear ${ }^{\circledR}$ ) was added to solubilize formazan. The plates were gently shaken at room

\footnotetext{
${ }^{1}$ http://rsb.info.nih.gov/ij/
} 
temperature for 5-10 min and read at $540 \mathrm{~nm}$ in an ELISA reader (Biochrom Asys Expert Plus ${ }^{\circledR}$ ). This assay was tested in duplicate and repeated three times.

\section{Statistical Analysis}

The results were expressed as mean \pm standard error (SE), and $P$-values $\leq 0.05$ were considered statistically significant. All statistical analyses were performed using GraphPad Prism version 6.00 for Windows (GraphPad Software, San Diego, CA, United States). Comparisons between two groups were conducted by Student's $t$-test (parametric data) or the MannWhitney test (non-parametric data). Multiple comparisons were performed by one-way analysis of variance (ANOVA) followed by Dunn's test.

\section{RESULTS}

\section{Characterization of Antifungal Effects of Leaf EE and EAF of $X$. prockia}

Xylosma prockia EE presented MIC values from 8 to $64 \mathrm{mg} / \mathrm{L}$ against C. gattii and C. neoformans (Figure 1A). Among the tested fractions, EAF exhibited the best results (higher yield and lower values of MIC) (Supplementary Table S1) and was chosen for the experiments. The EAF was effective against both C. gattii and C. neoformans, with MIC values of $0.5-8 \mathrm{mg} / \mathrm{ml}$ and MFC from 1 to $8 \mathrm{mg} / \mathrm{ml}$ (Figure 1A). Similar results were obtained for FLC (MIC of $2-16 \mathrm{mg} / \mathrm{L}$ ) (Figure 2A).

The time-dependent effects of EAF on $C$. gattii and C. neoformans viability were also investigated in a time-kill assay (Figures 2C,D). EAF MIC reduced $97.5 \%$ of C. gattii and $99 \%$ of $C$. neoformans growth when incubated for at 72 and $36 \mathrm{~h}$, respectively. C. gattii growth was reduced by $100 \%$ following $36 \mathrm{~h}$ of exposure to EAF at $2 \times \mathrm{MIC}$ and $4 \times \mathrm{MIC}$. A similar effect was observed for C. neoformans $24 \mathrm{~h}$ post incubation with EAF.

Ethyl acetate fraction was also tested in combination with FLC and AMB, drugs usually chosen to treat cryptococcosis (Mourad and Perfect, 2018). No interactions were observed between EAF and these antifungal drugs when assessed against C. gattii (ATCC 32068 and L27/01) and C. neoformans strains (ATCC 28957 and ATCC H99) (Figure 2B).

The high-performance liquid chromatographymass spectrometry (HPLC-MS) analysis of the EAF of

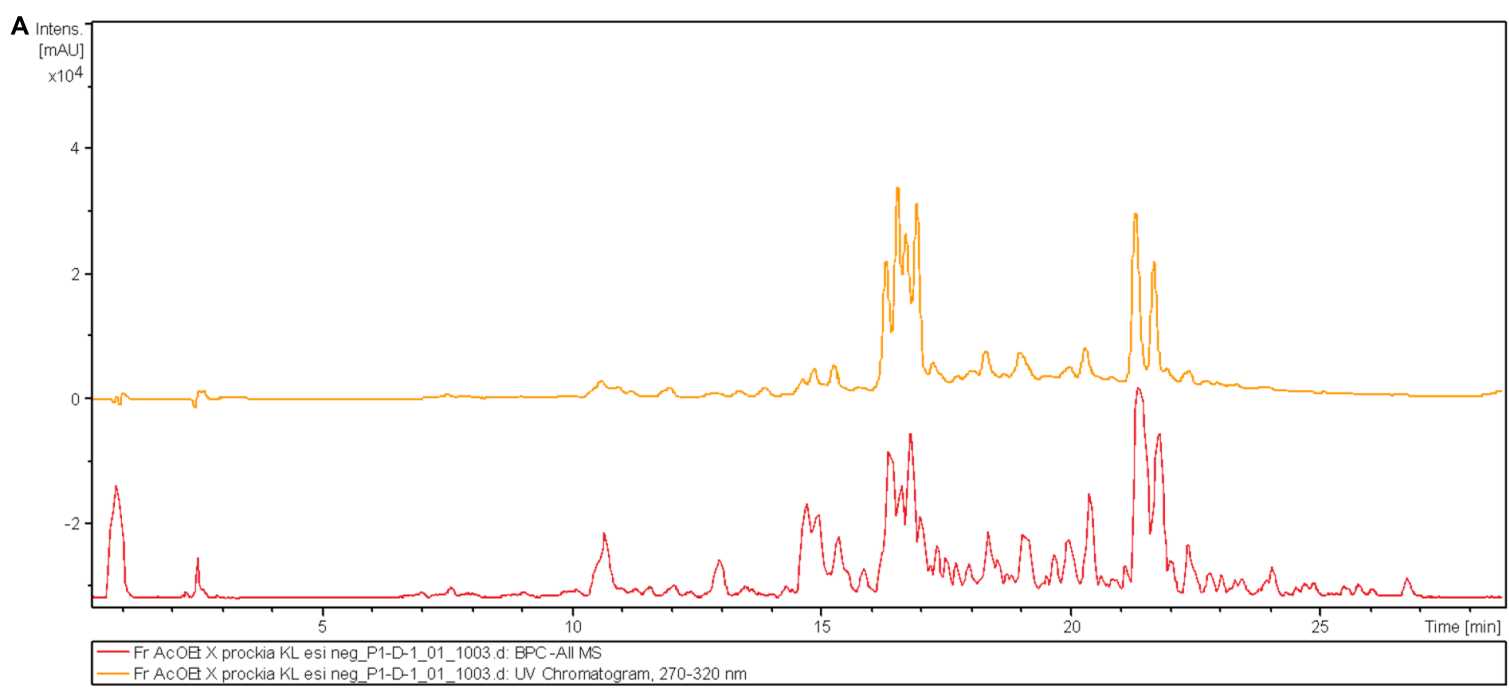

B<smiles>[R6]OC1C[C@](O)(C(=O)O)C[C@H]([O])[C@@H]1[R20]</smiles>

Type I: Caffeoyl-quinic acid derivatives 2: $\mathrm{R}_{1}=\mathrm{R}_{2}=\mathrm{H}, \mathrm{R}_{3}=$ caffeoyl 3: $\mathrm{R}_{1}$ :caffeoyl, $\mathrm{R}_{2}=\mathrm{R}_{3}=\mathrm{H}$

11: $\mathbf{R}_{1}, \mathrm{R}_{2}=$ glucosyl, $\mathrm{H}, \mathrm{R}_{3}=$ caffeoyl

$13: R_{1}=R_{2}=$ caffeoyl, $R_{2}=H$<smiles>[R]O[C@H]1O[C@H](COC(=O)/C=C/c2ccc(O)cc2)[C@@H](O)[C@H](O)[C@@H]1O</smiles>

Type II : p-coumaroyl glycosides 4: $: \mathrm{R}=\mathrm{H}$
5: $\mathrm{R}=\mathrm{H}$ 9: $\mathrm{R}=\mathrm{C}_{6} \mathrm{H}_{7} \mathrm{O}$

$10: \mathrm{R}=\mathrm{C}_{6} \mathrm{H}_{7} \mathrm{O}$

$12: \mathrm{R}=\mathrm{C}_{6} \mathrm{H}_{7} \mathrm{O}$

FIGURE 1 | High-performance liquid chromatography-ultraviolet (HPLC-UV) (270-320 nm, upper trace) and mass spectrometry (MS) (base peak chromatogram, lower trace) profile of ethyl acetate fraction (EAF) of Xylosma prockia leaves in the negative mode (-) (A). Detected compounds in EAF of $X$. prockia in electrospray ionization (ESI) (-) (B) 


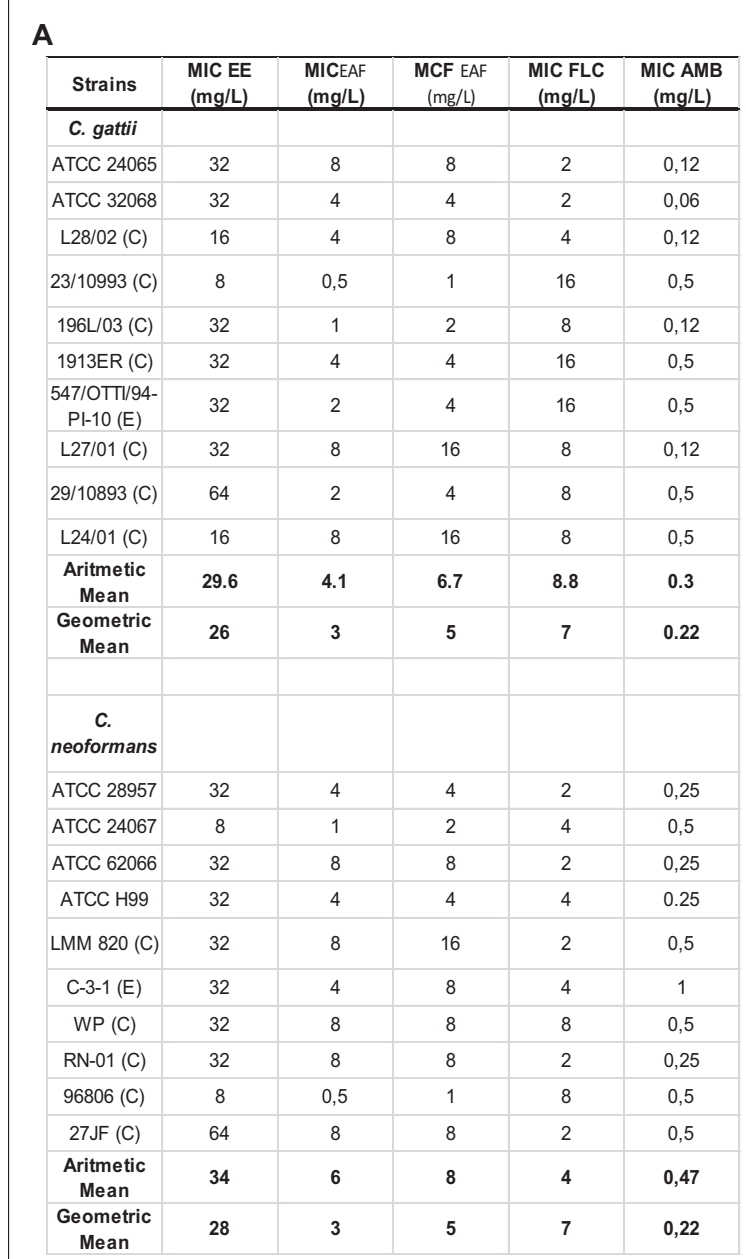
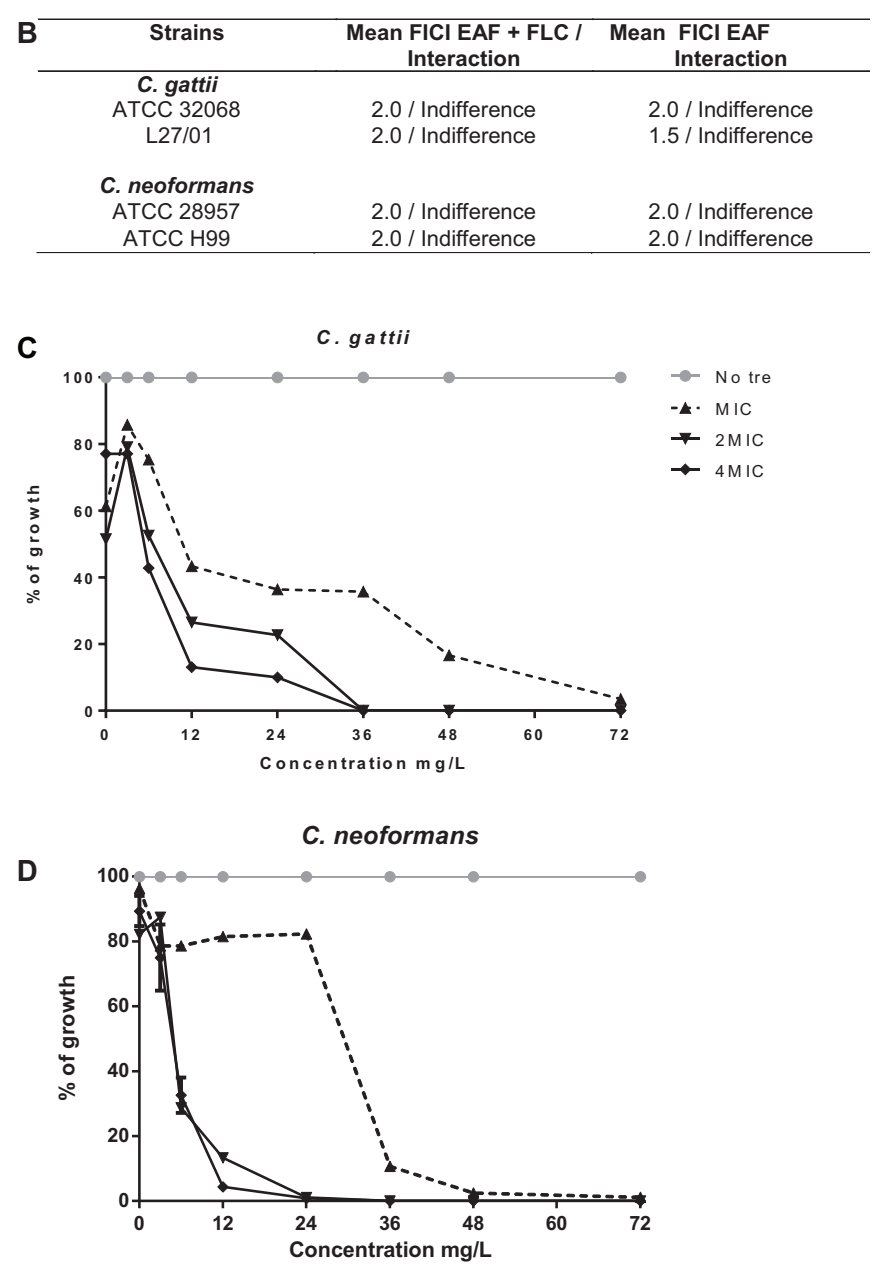

FIGURE 2 | Screening of the antimicrobial effects of Xylosma prockia leaves. Table listing the MIC of ethanolic extract (EE), ethyl acetate fraction (EAF), fluconazole (FLC), and amphotericin B (AMB) plus the MFC of EAF against Cryptococcus gattii and Cryptococcus neoformans (A). Table showing mean of fractional inhibitory concentration index $(\mathrm{FICl})$ and interaction between antifungal drugs and EAF against two strains of $C$. gattii and C. neoformans (B). Time-kill curves generated against two strains of $C$. gattii (C) and C. neoformans (D) at different concentrations of EAF. The results of the time-kill curve are expressed as the percentage of growth compared with growth of the control. Table showing mean of fractional inhibitory concentration index (FICI) and interaction between antifungal drugs and EAF against two strains of C. gattii and C. neoformans (D). ATCC, American Type Culture; E, Environmental; C, Clinical; MIC, Minimal inhibitory concentration; MFC, Minimal fungicidal concentration.

X. prockia obtained using electrospray ionization (ESI) in negative ionization mode allowed visualization of 15 major peaks (Figure 1), which were assembled in three distinct groups of compounds (I, caffeoylquinic acid derivatives; II, coumaroyl-glucoside derivatives; III, caffeoylglucoside/deoxyhexosyl-caffeoyl glucoside derivatives). Based on the fragmentation pattern (Supplementary Figure S2), type I compounds presented peaks corresponding to characteristic fragments of quinic acid at $\mathrm{m} / \mathrm{z} 191$ and caffeic acid at $\mathrm{m} / \mathrm{z}$ 179 and $\mathrm{m} / \mathrm{z}$ 161. Additionally, the observed product ions in each MS/MS spectrum allowed the isomeric differentiation of some compounds (Table 1). Type II and compounds 6-8 were identified as 6-p-coumaroyl-glucose or 6-caffeoyl-glucose derivatives, respectively, based on key fragmentation patterns (m/z 205 ions for coumaroyl and m/z 221 for caffeate derivatives).
The compounds having the highest relative abundance in the chromatogram showed $[\mathrm{M}-\mathrm{H}]^{-}$at $\mathrm{m} / \mathrm{z} 419.1342$, corresponding to a molecular formula of $\mathrm{C}_{21} \mathrm{H}_{24} \mathrm{O}_{9}$, being consistent with the presence of coumaroate, glucose, and an additional residue, $\mathrm{C}_{6} \mathrm{H}_{7} \mathrm{O}$, in the metabolites. Although similar compounds with a $\mathrm{C}_{6}$ residue attached to the sugar have been reported (Feistel et al., 2017), the preliminary spectroscopic data would indicate that they have different structures and that further isolation would be mandatory to assess the complete characterization of these isomeric compounds $(\mathbf{6}, 7$, and 8; and 9, 10, and 12).

The metabolites of group III, with $[\mathrm{M}-\mathrm{H}]^{-}$ion at $\mathrm{m} / \mathrm{z}$ 581, were identified as 6-caffeoyl-3-deoxyhexosyl glucoside derivatives, based on the product ions observed in their MS/MS spectra, mainly $\mathrm{m} / \mathrm{z} 487$ (loss of $\mathrm{C}_{6} \mathrm{H}_{7} \mathrm{O}$ moiety), 435 (loss of 
TABLE 1 | Hydroxycinnamic acid derivatives identified by high-performance liquid chromatography (HPLC)-electrospray ionization (ESI)-mass spectrometry (MS) in the ethyl acetate fraction (EAF) of Xylosma prockia.

\begin{tabular}{|c|c|c|c|c|c|c|c|c|c|c|}
\hline Number & Group & $\operatorname{Tr}(\min )$ & $\begin{array}{l}\text { Proposed } \\
\text { compound }\end{array}$ & $\begin{array}{l}\text { Molecular } \\
\text { formula }\end{array}$ & {$[M-H]^{-}(m / z)$} & $\begin{array}{c}\text { Calculated } \\
{[\mathrm{M}-\mathrm{H}]^{-}(\mathrm{m} / \mathrm{z})}\end{array}$ & $\begin{array}{l}\text { Error } \\
\text { (ppm) }\end{array}$ & $\begin{array}{l}\text { Precursor } \\
\text { ion }\end{array}$ & $\begin{array}{l}\text { Product ions } \\
\text { (relative } \\
\text { intensity) }\end{array}$ & References \\
\hline 1 & III & 10.1 & caffeoyl glucose & $\mathrm{C}_{15} \mathrm{H}_{18} \mathrm{O}_{9}$ & 341.0876 & 341.0878 & 0.5 & 341 & $\begin{array}{l}135 \text { (100), } 179 \\
(60), 161(55)\end{array}$ & \\
\hline 2 & 1 & 10.7 & $\begin{array}{l}\text { 5-caffeoyl-quinic } \\
\text { acid (5-CQA) }\end{array}$ & $\mathrm{C}_{16} \mathrm{H}_{18} \mathrm{O}_{9}$ & 353.0894 & 353.0878 & -4.6 & 353 & $\begin{array}{c}191(100), 179 \\
(70), 135(20)\end{array}$ & Ouyang et al., 2018 \\
\hline 3 & 1 & 10.9 & $\begin{array}{l}\text { 3-caffeoyl-quinic } \\
\text { acid (3-CQA) }\end{array}$ & $\mathrm{C}_{16} \mathrm{H}_{18} \mathrm{O}_{9}$ & 353.0862 & 353.0878 & 4.7 & 353 & $191(100)$ & Ouyang et al., 2018 \\
\hline 4 & $\|$ & 11.0 & coumaroyl-glucose & $\mathrm{C}_{15} \mathrm{H}_{18} \mathrm{O}_{8}$ & 325.0920 & 325.0929 & 2.9 & 325 & $\begin{array}{l}119(100), 145 \\
(50), 163(30)\end{array}$ & \\
\hline 5 & $\|$ & 12.1 & coumaroyl-glucose & $\mathrm{C}_{15} \mathrm{H}_{18} \mathrm{O}_{8}$ & 325.0941 & 325.0929 & -3.9 & 325 & $\begin{array}{l}119(100), 145 \\
(50), 163(30)\end{array}$ & \\
\hline 6 & III & 14.7 & caffeoyl-glucoside & $\mathrm{C}_{21} \mathrm{H}_{24} \mathrm{O}_{10}$ & 435.1302 & 435.1297 & -1.3 & 435 & $\begin{array}{l}281(60), 179 \\
(80), 161(100)\end{array}$ & \\
\hline 7 & III & 15.0 & caffeoyl-glucoside & $\mathrm{C}_{21} \mathrm{H}_{24} \mathrm{O}_{10}$ & 435.1307 & 435.1297 & -2.3 & 435 & $\begin{array}{l}281(60), 179 \\
(80), 161(100)\end{array}$ & \\
\hline 8 & III & 15.4 & caffeoyl-glucoside & $\mathrm{C}_{21} \mathrm{H}_{24} \mathrm{O}_{10}$ & 435.1304 & 435.1297 & -1.7 & 435 & $\begin{array}{l}281(60), 179 \\
(80), 161(100)\end{array}$ & \\
\hline 9 & $\|$ & 16.4 & $\begin{array}{l}\text { coumaroyl- } \\
\text { glucoside }\end{array}$ & $\mathrm{C}_{21} \mathrm{H}_{24} \mathrm{O}_{9}$ & 419.1342 & 419.1348 & 1.3 & 419 & $\begin{array}{c}265 \text { (100), } 205 \\
(60), 163(55) \\
145(50), 235 \\
(25)\end{array}$ & \\
\hline 10 & $\|$ & 16.6 & $\begin{array}{l}\text { coumaroyl- } \\
\text { glucoside }\end{array}$ & $\mathrm{C}_{21} \mathrm{H}_{24} \mathrm{O}_{9}$ & 419.1350 & 419.1348 & -0.7 & 419 & $\begin{array}{c}265 \text { (100), } 205 \\
(60), 163(55) \\
145(50), 235 \\
(25)\end{array}$ & \\
\hline 11 & 1 & 16.8 & $\begin{array}{l}\text { 5-caffeoyl-glucosyl- } \\
\text { quinic-acid }\end{array}$ & $\mathrm{C}_{22} \mathrm{H}_{28} \mathrm{O}_{14}$ & 515.1412 & 515.1406 & 0.3 & 515 & $\begin{array}{c}353(85), 191 \\
(100), 179(50) \\
135(15)\end{array}$ & $\begin{array}{l}\text { Jaiswal et al., 2014; } \\
\text { Ouyang et al., } 2018\end{array}$ \\
\hline 12 & $\|$ & 17.3 & $\begin{array}{l}\text { coumaroyl- } \\
\text { glucoside }\end{array}$ & $\mathrm{C}_{21} \mathrm{H}_{24} \mathrm{O}_{9}$ & 419.1364 & 419.1348 & -4.0 & 419 & $\begin{array}{c}265 \text { (100), } 205 \\
(60), 163(55) \\
145(50), 235 \\
(25)\end{array}$ & \\
\hline 13 & 1 & 18.3 & $\begin{array}{l}\text { 3,5-dicaffeoylquinic } \\
\text { acid }\end{array}$ & $\mathrm{C}_{25} \mathrm{H}_{24} \mathrm{O}_{12}$ & 515.1190 & 515.1195 & 0.9 & 515 & $\begin{array}{c}353 \text { (100), } 335 \\
(1), 191(30) \\
179(56), 173 \\
(72)\end{array}$ & Jaiswal et al., 2014 \\
\hline 14 & III & 21.3 & $\begin{array}{l}\text { caffeoyl } \\
\text { deoxyhexosyl } \\
\text { glucoside }\end{array}$ & $\mathrm{C}_{27} \mathrm{H}_{34} \mathrm{O}_{14}$ & 581.1867 & 581.1876 & 1.3 & 581 & $\begin{array}{c}161 \text { (100), } 435 \\
(54), 487(43), \\
179(34), 203 \\
(30), 427(17), \\
235(10)\end{array}$ & \\
\hline 15 & III & 21.7 & $\begin{array}{l}\text { caffeoyl } \\
\text { deoxyhexosyl } \\
\text { glucoside }\end{array}$ & $\mathrm{C}_{27} \mathrm{H}_{34} \mathrm{O}_{14}$ & 581.1877 & 581.1876 & -0.3 & 581 & $\begin{array}{c}161(100), 435 \\
(54), 487(43), \\
179(34), 203 \\
(30), 427(17), \\
235(10)\end{array}$ & \\
\hline
\end{tabular}

deoxyhexose), and $\mathrm{m} / \mathrm{z} 427$ and 346, with a deoxyhexose attached at C-4 of the glucose (Supplementary Figure S1).

\section{EAF Induces Oxidative Burst and Lipid Peroxidation}

Ethyl acetate fraction resulted in a significant increase of ROS (C. gattii $1 \mathrm{~h}$, no treatment: $0.014 \pm 0.0003 \mathrm{AU} / \mathrm{CFU}$ (arbitrary units of fluorescence/colony forming unit), EAF: $0.021 \pm 0.0001 \mathrm{AU} / \mathrm{CFU}, \mathrm{AMB}: 0.038 \pm 0.0007 \mathrm{AU} / \mathrm{CFU}$;
C. gattii $24 \mathrm{~h}$, no treatment: $0.053 \pm 0.006 \mathrm{AU} / \mathrm{CFU}$, EAF: $0.093 \pm 0.003 \mathrm{AU} / \mathrm{CFU}, \mathrm{AMB}: 0.101 \pm 0.003 \mathrm{AU} / \mathrm{CFU}$ C. neoformans $1 \mathrm{~h}$, no treatment: $0.014 \pm 0.0001 \mathrm{AU} / \mathrm{CFU}$, EAF: $0.022 \pm 0.0004 \mathrm{AU} / \mathrm{CFU}, \mathrm{AMB}: 0.026 \pm 0.0004 \mathrm{AU} / \mathrm{CFU}$; C. neoformans $24 \mathrm{~h}$, no treatment: $0.052 \pm 0.001 \mathrm{AU} / \mathrm{CFU}$, EAF: $0.094 \pm 0.002 \mathrm{AU} / \mathrm{CFU}, \mathrm{AMB}: 0.098 \pm 0.004 \mathrm{AU} / \mathrm{CFU}$; $P<0.05$ ) (Figures 3A,B) and peroxynitrite (C. gattii $1 \mathrm{~h}$, no treatment: $0.071 \pm 0.001 \mathrm{AU} / \mathrm{CFU}$, EAF: $0.010 \pm 0.001 \mathrm{AU} / \mathrm{CFU}$, AMB: $0.177 \pm 0.005 \mathrm{AU} / \mathrm{CFU}$; C. gattii $24 \mathrm{~h}$, no treatment: $0.156 \pm 0.002 \mathrm{AU} / \mathrm{CFU}, \mathrm{EAF}: 0.330 \pm 0.015 \mathrm{AU} / \mathrm{CFU}, \mathrm{AMB}$ 

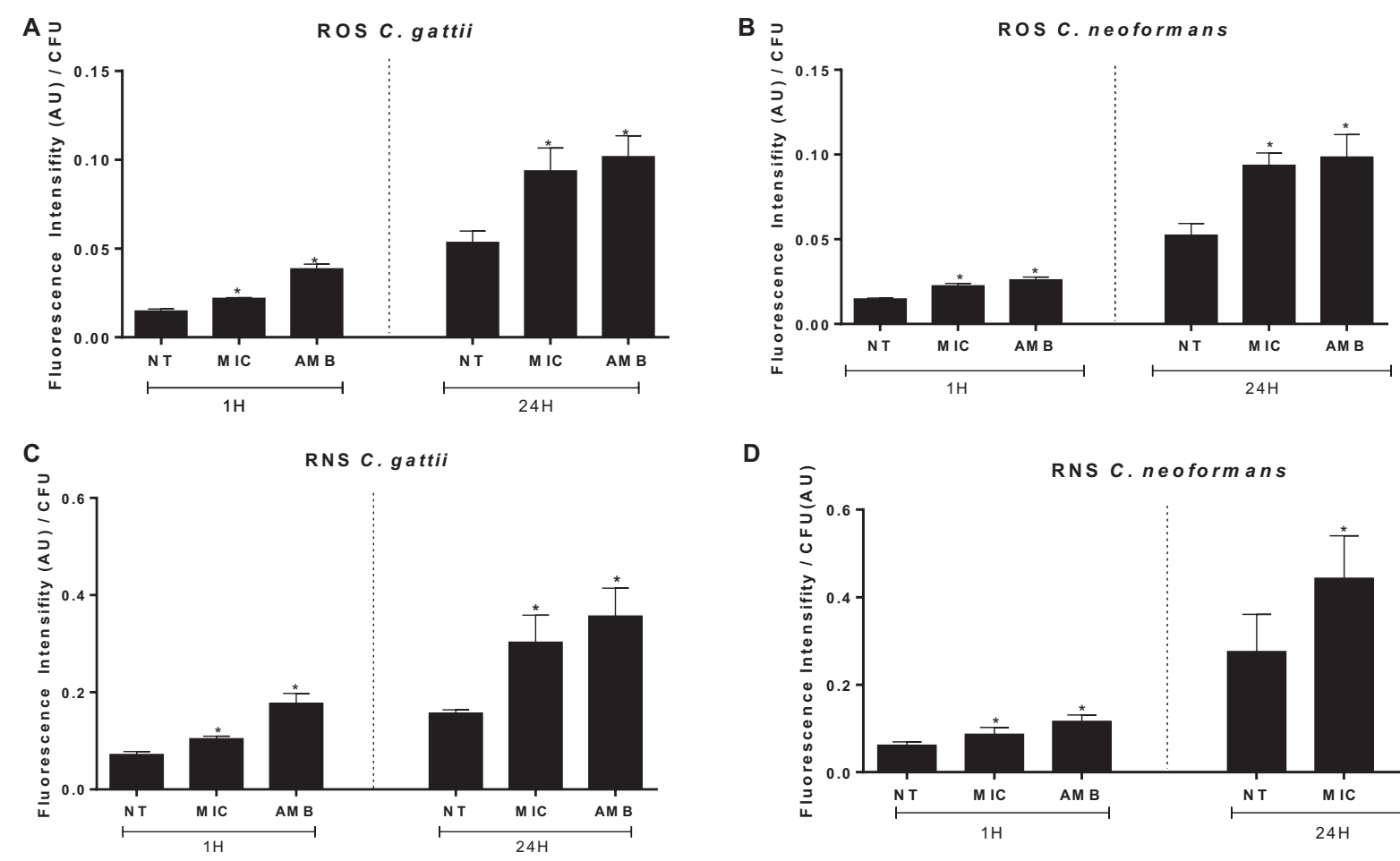

D

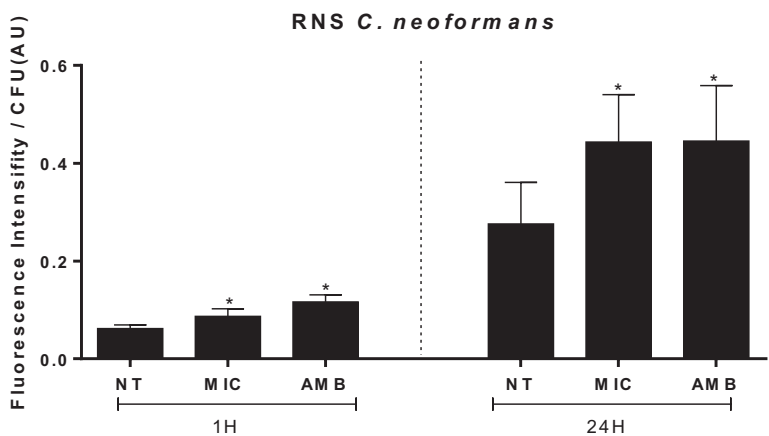

FIGURE 3 | Amounts of reactive oxygen (A,B) and nitrosative (C,D) species peroxynitrite induced by EAF and AMB (positive control) against Cryptococcus gattii (A-C) and Cryptococcus neoformans (B-D) within 1 and $24 \mathrm{~h}$. The results are expressed in arbitrary units of fluorescence (AU). Data are represented as the mean \pm SEM of two independent experiments in triplicate assays. An asterisk represents statistical differences between the treatments and the control $(P<0.05)$. EAF, ethyl acetate fraction; NT, no treatment; AMB, amphotericin B; MIC, minimal inhibitory concentration; ROS, reactive oxygen species; RNS, reactive nitrogen species.
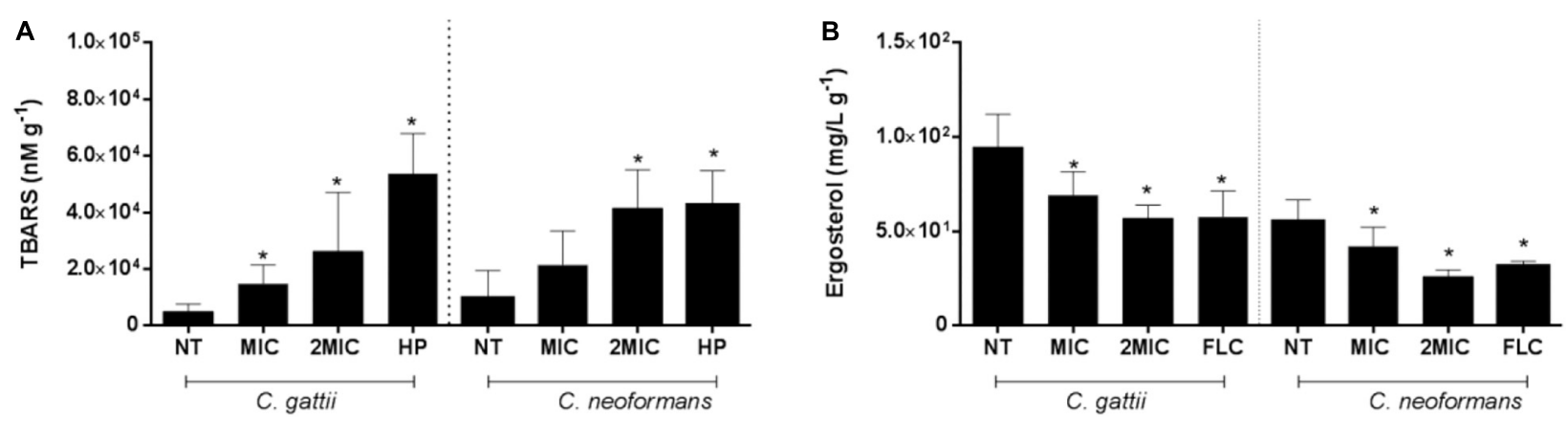

FIGURE 4 | Reduction of lipid peroxidation and ergosterol content are consequences of the treatment with EAF of Xylosma prockia. Amount of TBARS in Cryptococcus gattii and Cryptococcus neoformans cells after $24 \mathrm{~h}$ of EAF or HP (positive controls) treatment. The results are expressed in nanomolars per gram (A) Ergosterol levels of cells from C. gattii and C. neoformans after $24 \mathrm{~h}$ of EAF or FLC (positive control) treatments. Results are expressed in micrograms per milliliter per gram (B). Data of these two experiments are represented as the mean \pm SEM of two independent experiments in triplicate assays. An asterisk represents statistical differences between the treatments and the control $(P<0.05)$. EAF, ethyl acetate fraction; NT, no treatment; FLC, fluconazole; HP, hydrogen peroxide; MIC, minimal inhibitory concentration; TBARS, thiobarbituric acid-reactive substances.

$0.357 \pm 0.016 \mathrm{AU} / \mathrm{CFU}$; C. neoformans $1 \mathrm{~h}$, no treatment: $0.061 \pm 0.002$ AU/CFU, EAF: $0.086 \pm 0.004$ AU/CFU, AMB: $0.116 \pm 0.004 \mathrm{AU} / \mathrm{CFU}$; C. neoformans $24 \mathrm{~h}$, no treatment: $0.275 \pm 0.024$ AU/CFU, EAF: $0.443 \pm 0.027$ AU/CFU, AMB: $0.445 \pm 0.032 \mathrm{AU} / \mathrm{CFU} ; P<0.05$ ) levels (Figures 3C,D) in C. gattii and C. neoformans 1 and $24 \mathrm{~h}$ following incubation.
A similar stimulated effect was observed for EAF on the TBARS levels of $C$. gattii (no treatment: 5,008 $\pm 1,119 \mathrm{nM} \cdot \mathrm{g}^{-1}$, MIC EAF: $14,933 \pm 2,493 \mathrm{nM} \cdot \mathrm{g}^{-1}, 2 \times$ MIC EAF: $26,272 \pm 7,396 \mathrm{nM} \cdot \mathrm{g}^{-1}$, HP: $53,856 \pm 6,308 \mathrm{nM} \cdot \mathrm{g}^{-1}$; $P<0.05$ ) (Figure 4A) and C. neoformans (no treatment: $9,785 \pm 3,667 \mathrm{nM} \cdot \mathrm{g}^{-1}$, MIC EAF: $21,503 \pm 4,504 \mathrm{nM} \cdot \mathrm{g}^{-1}$ 
$2 \times$ MIC EAF: 41,563 \pm 5,096 $\mathrm{nM} \cdot \mathrm{g}^{-1}, \quad \mathrm{HP}:$ $42,674 \pm 4,563 \mathrm{nM} \cdot \mathrm{g}^{-1} ; P<0.05$ ) (Figure 4B), in comparison with vehicle-treated cells.

\section{EAF Does Not Affect Mitochondrial Membrane Potential}

Next, we attempted to analyze the effects of EAF in $\Delta \Psi \mathrm{m}$ using an assay based on the uptake and retention of Rho 123. The results of cells incubated for $24 \mathrm{~h}$ demonstrated no significant differences between EAF-treated cells and cells without treatment $(P>0.05)$ (Supplementary Figure S2).

\section{EAF Impairs Cell Membrane}

Ethyl acetate fraction promotes significant reduction of ergosterol content in Cryptococcus cells when treated with $1 \times \mathrm{MIC}$ and $2 \times \mathrm{MIC}$ of EAF (C. gattii, no treatment: $94.78 \pm 6.58 \mathrm{mg} / \mathrm{L} \cdot \mathrm{g}^{-1}$, MIC EAF: $69.30 \pm 4.371 \mathrm{mg} / \mathrm{L} \cdot \mathrm{g}^{-1}, 2 \times$ MIC EAF: $56.95 \pm 2.85 \mathrm{nM} \cdot \mathrm{g}^{-1}$, FLC: $\left.53.85 \pm 6.30 \mathrm{nM} \cdot \mathrm{g}^{-1} ; P<0.05\right)$ (C. neoformans, no treated: $55.39 \pm 4.01 \mathrm{mg} / \mathrm{L} \cdot \mathrm{g}^{-1}$, MIC EAF: $42.08 \pm 3.97 \mathrm{mg} / \mathrm{L} \cdot \mathrm{g}^{-1}, 2 \times$ MIC EAF: $26.02 \pm 1.38 \mathrm{nM} \cdot \mathrm{g}^{-1}$, FLC: $31.65 \pm 1.04 \mathrm{nM} \cdot \mathrm{g}^{-1} ; P<0.05$ ) in both species (Figure 4B).

Interestingly, cells treated with subinhibitory concentrations of EAF had membrane damages, with less CFSE death (C. gattii, no treatment: $27.75 \pm 1.51$ AU, EAF: $9.92 \pm 0.44 \mathrm{AU} ; P<0.05$ ) (C. neoformans, no treatment: $29.90 \pm 1.52$ AU, EAF: $10.50 \pm 0.50$ AU; $P<0.05)$ (Figure 5A). These results indicate that the EAF causes cell membrane impairment, with a reduction in the amount of ergosterol.
It is important to note that the results of the assays with sorbitol showed no alterations of MIC when Cryptococcus cells were exposed to the osmotic protector sorbitol (Lee and Kim, 2016), indicating that damaging effects of the EAF cannot be recovered in the presence of osmoprotectants such as sorbitol.

\section{Morphological Alterations}

Following the results obtained, we researched the ability of C. gattii and C. neoformans of adapting to the stress caused by EAF through changing morphometric parameters. Morphometric analysis showed that cells exposed to subinhibitory concentrations of EAF have a significantly reduced surface/volume (S/V) ratio for $C$. gattii (no treatment: $1.24 \pm 0.02 \mathrm{~S} / \mathrm{V}$, EAF: $1.36 \pm 0.02 \mathrm{~S} / \mathrm{V} ; P<0.05)$ and C. neoformans (no treatment: $1.25 \pm 0.02$ S/V, EAF: $1.41 \pm 0.02 \mathrm{~S} / \mathrm{V} ; \quad P<0.05$ ) (Figures 5B,E) strains. No alterations for capsule size measurements $(P>0.05)$ were observed (Figure 5C).

No changes were observed in the cellular superficial charges in comparison to the control growth $(P>0.05)$ (Figure 5D). These results corroborate capsule analyses, since the capsule polysaccharides contribute considerably to the negative cell charge (Johnston and May, 2013).

\section{Thermodynamics Data}

Aiming to analyze the molecular interactions between the EAF and cryptococcal cells, in this process, enthalpy changes were determined by ITC. Figure $\mathbf{6}$ shows that the interaction of the EAF with cryptococcal cells did not cause alterations in enthalpy,
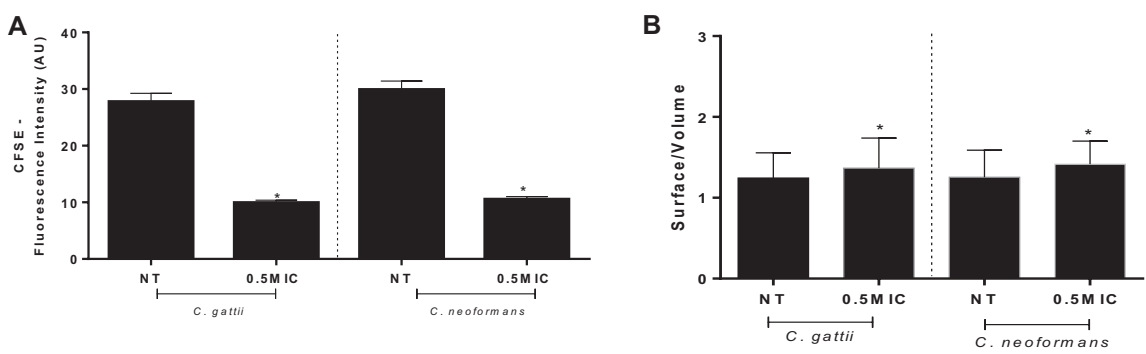

C
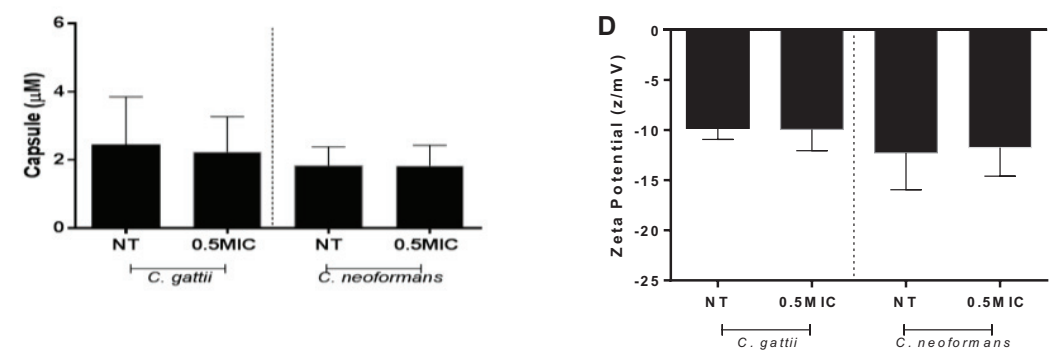

E Not treated

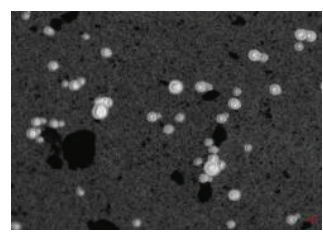

EAF treated

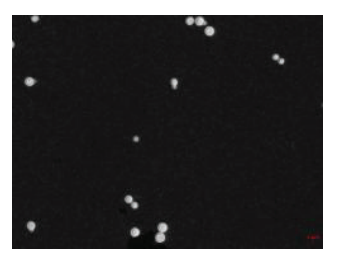

FIGURE 5 | Ethyl acetate fraction stress impairs the cell membrane and increases the surface/volume ratio with no changes on the cell net charge. Cells exposed to $0.5 \times$ MIC of EAF for $24 \mathrm{~h}$ were less labeled than the non-treated cells for both species. Data are represented in arbitrary units of fluorescence (AU) (A). Morphometric data are obtained by India ink and are represented by a ratio of surface/volume for cell size (B) and micromolars for capsule (C). Zeta potential data are expressed in $\mathrm{z} / \mathrm{mV}$ (D). Stained cells (E). Data of experiments are represented as the mean \pm SEM of two independent experiments in triplicate assays. An asterisk represents statistical differences between the treatments and the control ( $p<0.05)$. EAF, Ethyl acetate fraction; NT, No treatment; MIC, Minimal inhibitory concentration; CFSE, Carboxyfluorescein succinimidyl ester. 


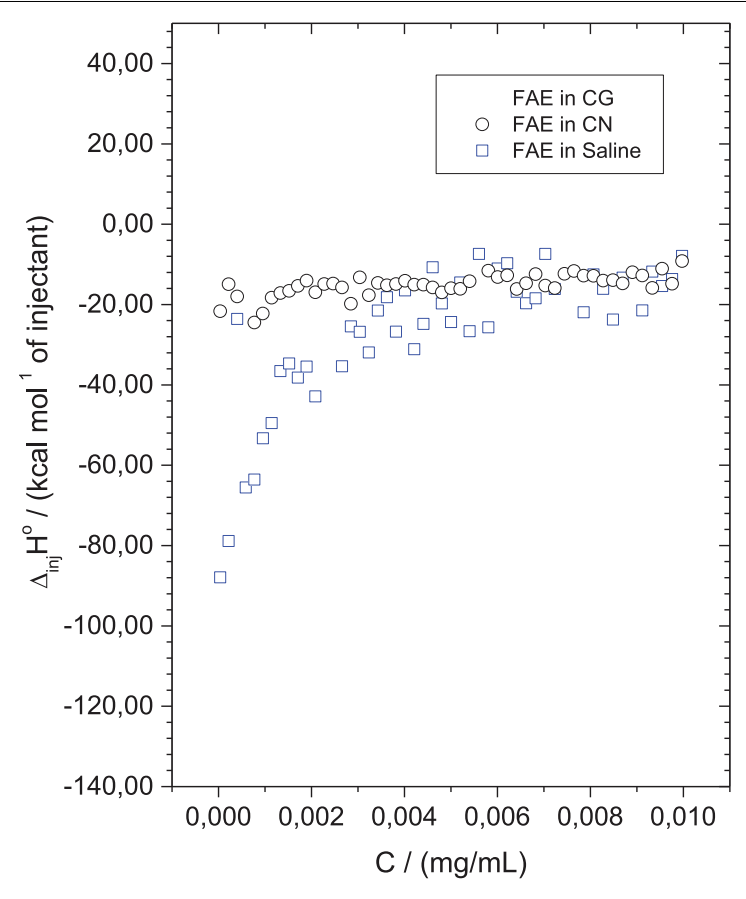

FIGURE 6 | Ethyl acetate fraction (EAF) did not interact significantly with the surface of cryptococcal cells. Calorimetric titration curve for the dilution of concentrated EAF into saline solution (control) (blue square), Cryptococcus gattii (black squares), and Cryptococcus neoformans. Each titration experiment consisted of 51 successive injections of $5 \mu \mathrm{l}$ of EAF at $1,000 \mathrm{mg} / \mathrm{L}$ in $1.5 \mathrm{ml}$ of cell suspension at $1 \times 10^{6} \mathrm{CFU} / \mathrm{ml}$.

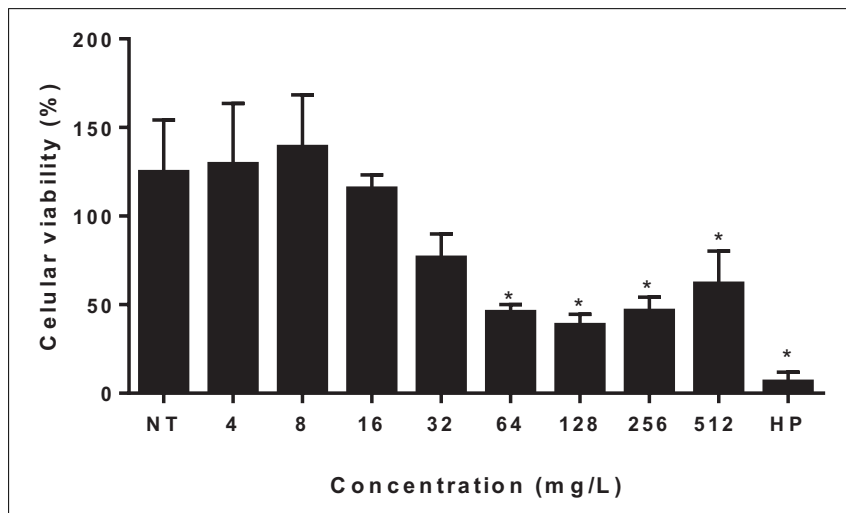

FIGURE 7 | Ethyl acetate fraction cytotoxicity assay. Each bar represents the mean + standard deviation of the percentage of cell viability expressed in percentage of our independent experiments performed in triplicate considering the viability of untreated cells as $100 \%$. *Statistical significance $(P>0.05)$. EAF, Ethyl acetate fraction; NT, No treatment; HP, Hydrogen peroxide.

since the values of the test groups were similar to those of the blank experiment (EAF in saline).

\section{Cytotoxicity Assay}

MTT assay was performed in order to examine the cytotoxic effect of the EAF against PBMCs. These cells were treated with
EAF in different concentrations, ranging from 4 to $512 \mathrm{mg} / \mathrm{L}$. No significant cytotoxic effect was observed in normal PBMC at concentrations from 4 to $32 \mathrm{mg} / \mathrm{ml}$ (Figure 7).

\section{DISCUSSION}

Our results showed promising values of MIC for EAF against C. gattii and C. neoformans, since values ranged from 0.5 to $16 \mathrm{mg} / \mathrm{l}$ for both species. According to Ríos and Recio (2005), concentrations below $100 \mu \mathrm{g} / \mathrm{ml}$ for extracts and below $10 \mu \mathrm{g} / \mathrm{ml}$ for isolated compounds can be considered promising sources of substances with antimicrobial activity, opening new possibilities for the discovery of active molecules for the treatment of fungal infections. Newman and Cragg (2016), in a study evaluating the origin of drugs approved by the Food and Drug Administration (FDA) in the last 34 years, indicate that among the 221 new antimicrobials approved in that period, about $67 \%$ are related to natural products. Since currently available antifungal drugs do not fully meet the clinical needs either for the development of resistance or for high toxicity, it is necessary to continuously search for new chemical entities for the treatment of infections. In this context, natural products and derivatives are an invaluable source of substances with biological potential.

The MFC values of EAF against C. gattii and C. neoformans were similar to MIC values, ranging from 2 to $16 \mathrm{mg} / \mathrm{L}$ (Figure 2A), with an MFC/MIC ratio between 1 and 2. These results for antifungal tests or assays suggest that the EAF had a fungicidal effect on all tested yeasts strains (Peixoto et al., 2017). Time-kill curves demonstrated that the EAF kills cryptococcus cells in a time-concentration-dependent manner, similar to what can be seen in time-kill curves of AMB described by Burgess and Hastings (2000) and Cantón et al. (2004). It is important to note that no significant cytotoxic effect was observed in normal PBMCs in concentrations from 4 to $32 \mathrm{mg} / \mathrm{ml}$ that significantly affected cryptococcal cells (MIC ranged from 1 to $8 \mathrm{mg} / \mathrm{L}$ ), suggesting that the effect of the EAF was more selective for yeasts than for PBMCs.

Another important point is that the analysis of the combination between FLC/AMB and EAF in vitro suggests that EAF does not impair the action of these drugs, but more studies are necessary to confirm this hypothesis.

To our knowledge, there are no studies about antimicrobial activity of $X$. prockia leaves, and there are just a few concerning other species of Xylosma, and these are limited to MIC evaluation. The antimicrobial activity of aqueous and alcoholic extracts of Xylosma longifolium leaves was observed against Staphylococcus aureus, Bacillus subtilis, and Candida albicans (Parveen and Ghalib, 2012). Other authors showed that $X$. longifolium methanol leaf extract has an inhibitory effect against Trichophyton ajelloi MTCC 4878 (140.62 mg/L) (Devi et al., 2013), with a much higher MIC than that observed for the EAF of $X$. prockia in our study $(\leq 16 \mathrm{mg} / \mathrm{ml})$.

Our results pointed that $X$. prockia EAF has hydroxycinnamic acid derivatives as majority compounds. Interestingly, although phenolic compounds are usually reported as free radical scavengers, our data demonstrate that EAF stimulates the 
production of intracellular oxidative and nitrosative species in cryptococcal cells. After 1 and $24 \mathrm{~h}$ of treatment with EAF, a significant oxidative burst was observed, but no modifications in mitochondrial membrane potential (Supplementary Figure S3) of yeast cells from both species. It is important to note that the straight connection between the ROS and the mitochondrial membrane potential is absent (Zhang et al., 2015). Several studies demonstrated that polyphenols can act as prooxidants under certain conditions, producing free radicals and causing cell injury (Eghbaliferiz and Iranshahi, 2016). The prooxidant activity of hydroxycinnamic acids was observed in the presence of $\mathrm{Cu}$ (II) with DNA damage (Zheng et al., 2008). It has been shown that curcumin- and resveratrol-mediated apoptosis is related to the increase in the concentrations of ROS (Heo et al., 2018). Epigallocatechin gallate from green tea can cause oxidative stress-related responses in Saccharomyces cerevisiae and can produce $\mathrm{H}_{2} \mathrm{O}_{2}$ in a weak alkaline medium (Maeta et al., 2007).

Therefore, we verified if EAF could induce lipid peroxidation in cryptococcal cells. TBARS levels were significantly high when both yeasts were treated with this fraction. The literature demonstrated considerable differences between these two species concerning the adaptation to stress condition (Jain and Fries, 2008; Hansakon et al., 2019). For example, Hamilton and Holdom (1997) demonstrated that $\mathrm{Cu}$ and $\mathrm{Zn}$ superoxide dismutase activity was present in supernatants of stationaryphase cultures of $C$. neoformans isolates, but undetectable in culture supernatants from C. gattii isolates.

We then assessed the ability of the EAF to modify the cryptococcal membrane. The lipid composition of the fungal cell membrane is predominantly composed of sterols, glycerophospholipids, and sphingolipids, and this structure is the most common target of anticryptococcal drugs (Sant et al., 2016). Interestingly, we observed that EAF impairs the cell membrane (Figure 5A), with a reduction of ergosterol content (Figure 4B). It is important to note that experiments with sorbitol indicate that this osmotic protectant does not impair the activity of the EAF against yeasts, since the MIC did not vary.

As far as we know, there is no study on the effect of phenolic acid derivatives on the ergosterol composition or biosynthesis, but data about mode of action of several other phenolic compounds provide some clues. Eugenol, methyl-eugenol, epigallocatechin-3-gallate, thymol, and carvacrol cause a reduction in ergosterol amounts in Candida, affecting the cell membrane (Navarro-Martínez et al., 2006; Ahmad et al., 2010, 2011).

To better understand how cryptococcal cells adapt to EAF stress, we performed some experiments exposing yeasts cells in subinhibitory concentrations of EAF $(0.5 \times$ MIC). EAF induced damage to the cell membrane and diminished its size with an increase in the S/V ratio. Cryptococcus cells are plastic, since they can modify their morphotypes (yeast, pseudohypha, or hypha) or sizes (micro or giant cells), depending on environmental factors (Navarro-Martínez et al., 2006; May et al., 2016). Small cells, and, consequently, the high $\mathrm{S} / \mathrm{V}$ ratio, adapt quickly to changes in stress conditions. Researchers observed that small cells were adapted for growth in the presence of macrophages
(Feldmesser et al., 2001), azoles (Nosanchuk et al., 1999; Ferreira et al., 2015), AMB (Nosanchuk et al., 1999), and terbinafine (Guerra et al., 2012). However, other studies have shown that capsule growth has a high energy cost for the cell (Ferreira et al., 2015), and this can explain why the cells do not expand the capsule in the presence of EAF. Due to the capsule's contribution to the negative charge of Cryptococcus cells (Nosanchuk and Casadevall, 1997), we did not find alterations in the ZP.

The binding forces between molecules and ligands may include electrostatic interactions, hydrogen bonds, Van der Waals interactions, and hydrophobic interactions. Thermodynamic parameters of the binding reactions reveal a valuable insight into the types of forces involved (Du et al., 2016). Our thermodynamic ITC data showed very low differences of enthalpies between EAF/yeasts and EAF/blank titrations, demonstrating that molecular interactions between the EAF and the surface of cryptococcal cells are very weak. This suggests that cell death caused by EAF in C. gattii and C. neoformans might be mainly mediated by intracellular target(s), probably through oxidative burst. However, further studies are needed to confirm this hypothesis.

\section{DATA AVAILABILITY STATEMENT}

All datasets generated for this study are included in the article/Supplementary Material.

\section{AUTHOR CONTRIBUTIONS}

MS and AS executed, analyzed, and interpreted the data for plant extraction and fractionation. IR, GS, and GC executed, analyzed, and interpreted the data for liquid chromatography and mass spectrometry. MF, GF, JCS, JR, EF, GJF, and AM executed, analyzed, and interpreted the data for tests about morphologic cell surface, ergosterol content, cellular wall integrity, lipid peroxidation, and oxidative burst from the interaction of EAF with cryptococcal cells. LS, JRS, WN, and EF executed, analyzed, and interpreted the data for tests about lysosomal and mitochondrial integrity from the interaction of EAF with cryptococcal cells. ÂD executed, analyzed, and interpreted the data for tests about thermodynamic changes from the interaction of eugenol with cryptococcal cells. LM executed, analyzed, and interpreted the data for tests about cytotoxicity. KL, GF, and DS conceptualized or designed all the work, prepared the article and translated into English.

\section{FUNDING}

This work was supported by Fundação de Amparo a Pesquisa do Estado de Minas Gerais (Research Support Foundation of the State of Minas Gerais) (FAPEMIG: APQ 02194/14, APQ 03606/16, and APQ 03536/16), Conselho Nacional de Desenvolvimento Cientiìfico e Tecnoloìgico (National Council for Scientific and Technological Development) 
(APQ 484456/2013-0, CNPq 311913/2017-2, and CNPq 437418/2018-9), Financiadora de Estudos e Pesquisas (Studies and Projects Financing Foundation) (FINEP 0633/13), and the International Office of the Federal University of Juiz de Fora (Labint/DRI/UFJF).

\section{REFERENCES}

Ahmad, A., Khan, A., Akhtar, F., Yousuf, S., Xess, I., Khan, L. A., et al. (2011). Fungicidal activity of thymol and carvacrol by disrupting ergosterol biosynthesis and membrane integrity against Candida. Eur. J. Clin. Microbiol. Infect. Dis. 30, 41-50. doi: 10.1007/s10096-010-1050-8

Ahmad, A., Khan, A., Manzoor, N., and Khan, L. A. (2010). Evolution of ergosterol biosynthesis inhibitors as fungicidal against Candida. Microb. Pathog. 48, 35-41. doi: 10.1016/j.micpath.2009.10.001

Alves, J. C. O., Ferreira, G. F., Santos, J. R., Silva, L. C. N., Rodrigues, J. F. S., Neto, W. R. N., et al. (2017). Eugenol induces phenotypic alterations and increases the oxidative burst in Cryptococcus. Front. Microbiol. 8:2419. doi: 10.3389/fmicb. 2017.02419

Arthington-Skaggs, B. A., Jradi, H., Desai, T., and Morrison, C. J. (1999). Quantitation of ergosterol content: novel method for determination of fluconazole susceptibility of Candida albicans. J. Clin. Microbiol. 370, 33323337. doi: 10.1128/jcm.37.10.3332-3337.1999

Bongomin, F., Oladele, R. O., Gago, S., Moore, C. B., and Richardson, M. D. (2018). A systematic review of fluconazole resistance in clinical isolates of Cryptococcus species. Mycoses 61, 290-297. doi: 10.1111/myc.12747

Breivik, O. N., and Owades, J. L. (1957). Spectrophotometric semimicrodetermination of ergosterol in yeast. J. Agr. Food Chem. 5, 360-363. doi: 10.1021/jf60075a005

Burgess, D. S., and Hastings, R. W. (2000). A comparison of dynamic characteristics of fluconazole, itraconazole, and amphotericin B against Cryptococcus neoformans using time-kill methodology. Diagn. Microbiol. Infect. Dis. 38, 87-93. doi: 10.1016/s0732-8893(00)00173-5

Cantón, E., Pemán, J., Gobernado, M., Viudes, A., and Espinel-Ingrof, A. (2004). Patterns of Amphotericin B Killing Kinetics against Seven Candida Species. Antimicrob. Agents Chemother. 48, 2477-2482. doi: 10.1128/aac.48.7.24772482.2004

Castro, S. B. R., Leal, C. A. G., Freire, F. R., Carvalho, D. A., Oliveira, D. F., and Figueiredo, H. C. P. (2008). Antibacterial activity of plant extracts from Brazil against fish pathogenic bacteria. Braz. J. Microb. 39, 756-760. doi: 10.1590/ s1517-83822008000400030

Davison, E. K., and Brimble, M. A. (2019). Natural product derived privileged scaffolds in drug discovery. Curr. Opin. Chem. Biol. 52, 1-8. doi: 10.1016/j.cbpa. 2018.12.007

Devi, W. R., Singh, S. B., and Singh, C. B. (2013). Antioxidant and antidermatophytic properties leaf and stem bark of Xylosma longifolium Clos. BMC Complement. Altern. Med. 13:155. doi: 10.1186/1472-6882-13-155

Du, X., Li, Y., Xia, Y. L., Ai, S. M., Liang, J., Sang, P., et al. (2016). Insights into protein-ligand interactions: mechanisms, models, and methods. Int. J. Mol. Sci. 17, E144. doi: 10.3390/ijms17020144

Eghbaliferiz, S., and Iranshahi, M. (2016). Prooxidant activity of polyphenols, flavonoids, anthocyanins and carotenoids: updated review of mechanisms and catalyzing metals. Phytother. Res. 30, 1379-1391. doi: 10.1002/ptr.5643

Feistel, F., Paetz, C., Lorenz, S., Beran, F., Kunert, G., and Schneider, B. (2017). Idesia polycarpa (Salicaceae) leaf constituents and their toxic effect on Cerura vinula and Lymantria dispar (Lepidoptera) larvae. Phytochemistry 143, 170-179. doi: 10.1016/j.phytochem.2017.08.008

Feldmesser, M., Kress, Y., and Casadevall, A. (2001). Dynamic changes in the morphology of Cryptococcus neoformans during murine pulmonary infection. Microbiology 147(Pt 8), 2355-2365. doi: 10.1099/00221287-147-8-2355

Ferreira, G. F., Baltazar, L. M., Santos, J. R., Monteiro, A. S., Fraga, L. A., ResendeStoianoff, M. A., et al. (2013). The role of oxidative and nitrosative bursts caused by azoles and amphotericin B against the fungal pathogen Cryptococcus gattii. J. Antimicrob. Chemother. 68, 1801-1811. doi: 10.1093/jac/dkt114

Ferreira, G. F., Pinto, B. L. S., Souza, E. B., Viana, J. L., Zagmignan, A., Santos, J. R., et al. (2016). Biophysical effects of a polymeric biosurfactant in Candida krusei

\section{SUPPLEMENTARY MATERIAL}

The Supplementary Material for this article can be found online at: https://www.frontiersin.org/articles/10.3389/fmicb. 2019.03114/full\#supplementary-material

and Candida albicans cells. Mycopathologia 181, 799-806. doi: 10.1007/s11046016-0054-Z

Ferreira, G. F., Santos, J. R., Costa, M. C., Holanda, R. A., Denadai, A. M. L., Freitas, G. J., et al. (2015). Heteroresistance to itraconazole alters the morphology and increases the virulence of Cryptococcus gattii. Antimicrob. Agents Chemother. 59, 4600-4609. doi: 10.1128/aac.00466-15

Guerra, C. R., Ishida, K., Nucci, M., and Rozental, S. (2012). Terbinafine inhibits Cryptococcus neoformans growth and modulates fungal morphology. Mem. Inst. Oswaldo Cruz 107, 582-590. doi: 10.1590/s0074-02762012000500003

Hamilton, A. J., and Holdom, M. D. (1997). Biochemical comparison of the $\mathrm{Cu}, \mathrm{Zn}$ superoxide dismutases of Cryptococcus neoformans var. neoformans and Cryptococcus neoformans var. gattii. Infect. Immun. 65, 488-494. doi: 10.1128/ iai.65.2.488-494.1997

Hansakon, A., Mutthakalin, P., Ngamskulrungroj, P., Chayakulkeeree, M., and Angkasekwinai, P. (2019). Cryptococcus neoformans and Cryptococcus gattii clinical isolates from Thailand display diverse phenotypic interactions with macrophages. Virulence 10, 26-36. doi: 10.1080/21505594.2018.1556150

Heo, J. R., Kim, S. M., Hwang, K. A., Kang, J. H., and Choi, K. C. (2018). Resveratrol induced reactive oxygen species and endoplasmic reticulum stress-mediated apoptosis, and cell cycle arrest in the A375SM malignant melanoma cell line. Int. J. Mol. Med. 42, 1427-1435. doi: 10.3892/ijmm.2018.3732

Herkert, P. F., Hagen, F., Pinheiro, R. L., Muro, M. D., Meis, J. F., and Queiroz-Telles, F. (2017). Ecoepidemiology of Cryptococcus gattii in developing countries.". J. Fungi (Basel) 3, 62-74. doi: 10.3390/jof3040062

Institute Clinical and Laboratory Standards [CLSI] (2008). Reference Method for Broth Dilution Antifungal Susceptibility Testing of Yeasts: Approved Standard M27-A3. Wayne, PA: CLSI.

Jain, N., and Fries, B. C. (2008). Phenotypic switching of Cryptococcus neoformans and Cryptococcus gattii. Mycopathologia 166, 181-188. doi: 10.1007/s11046008-9137-9

Jaiswal, R., Müller, H., Müller, A., Karar, M. G., and Kuhnert, N. (2014). Identification and characterization of chlorogenic acids, chlorogenic acid glycosides and flavonoids from Lonicera henryi L. (Caprifoliaceae) leaves by LC-MSn. Phytochemistry. 108, 252-263. doi: 10.1016/j.phytochem.2014. 08.023

Johnston, S. A., and May, R. C. (2013). Cryptococcus interactions with macrophages: evasion and manipulation of the phagosome by a fungal pathogen. Cell. Microbiol. 15, 403-411. doi: 10.1111/cmi.12067

Lee, H. S., and Kim, Y. (2016). Antifungal activity of Salvia miltiorrhiza against Candida albicans is associated with the alteration of membrane permeability and (1,3)- $\beta$-d-glucan synthase activity. J. Microbiol. Biotechnol. 26, 610-617. doi: 10.4014/jmb.1511.11009

Li, Y., Yue, Q., Jayanetti, D. R., Swenson, D. C., Bartholomeusz, G. A., An, Z., et al. (2017). Anti-cryptococcus phenalenones and cyclic tetrapeptides from auxarthron pseudauxarthron. J. Nat. Prod. 807, 2101-2109. doi: 10.1021/acs. jnatprod.7b00341

Longhi, S. J., Brena, D. A., Gomes, J. F., Narvaes, I. S., Berger, A., and Soligo, A. J. (2006). Classificação e caracterização de estágios sucessionais em remanescentes de floresta ombrófila mista na flora de São Francisco de Paula. Brasil. Ciência Florestal 16, 113-125.

Maeta, K., Nomura, W., Takatsume, Y., Izawa, S., and Inoue, Y. (2007). Green tea polyphenols function as prooxidants to activate oxidative-stress-responsive transcription factors in yeasts. Appl. Environ. Microbiol. 73, 572-580. doi: 10. 1128/AEM.01963-06

Magalhães, T. F., Silva, C. M., Fátima, A., Silva, D. L., Modolo, L. V., Martins, C. V., et al. (2013). Hydroxyaldimines as potent in vitro anticryptococcal agents. Lett. Appl. Microbiol. 57, 137-143. doi: 10.1111/lam.12086

May, R. C., Stone, N. R., Wiesner, D. L., Bicanic, T., and Nielsen, K. (2016). Cryptococcus: from environmental saprophyte to global pathogen. Nat. Rev. Microbiol. 14, 106-117. doi: 10.1038/nrmicro.2015.6 
Maziarz, E. K., and Perfect, J. R. (2016). Cryptococcosis. Infect. Dis. Clin. North. Am. 30, 179-206. doi: 10.1016/j.idc.2015.10.006

Monteiro, A. S., Miranda, T. T., Lula, I., Denadai, A. M. L., Sinisterra, R. D., Santoro, M. M., et al. (2011). Inhibition of Candida albicans CC biofilms formation in polystyrene plate surfaces by biosurfactant produced by Trichosporon montevideense CLOA72. Colloids Surf. B Biointerfaces 84, 467-476. doi: 10.1016/j.colsurfb.2011.02.001

Mosaddik, M. A., Banbury, L., Forster, P., Booth, R., Markham, J., Leach, D., et al. (2004). Screening of some Australian Flacourtiaceae species for in vitro antioxidant, cytotoxic and antimicrobial activity. Phytomedicine 11, 461-466. doi: 10.1016/j.phymed.2003.12.001

Mosmann, T. (1983). Rapid colorimetric assay for cellular growth and survival: application to proliferation and cytotoxicity assays. J. Immunol. Methods 65, 55-63. doi: 10.1016/0022-1759(83)90303-4

Mourad, A., and Perfect, J. R. (2018). The war on cryptococcosis: a review of the antifungal arsenal. Mem. Inst. Oswaldo Cruz 113:e170391. doi: 10.1590/007402760170391

Navarro-Martínez, M. D., García-Cánovas, F., and Rodríguez-López, J. N. (2006). Tea polyphenol epigallocatechin-3-gallate inhibits ergosterol synthesis by disturbing folic acid metabolism in Candida albicans. J. Antimicrob. Chemother. 57, 1083-1092. doi: 10.1093/jac/dkl124

Newman, D. J., and Cragg, G. M. (2016). Natural products as sources of new drugs from 1981 to 2014. J. Nat. Prod. 79, 629-661. doi: 10.1021/acs.jnatprod.5b01055

Nosanchuk, J. D., and Casadevall, A. (1997). Cellular charge of Cryptococcus neoformans: contributions from the capsular polysaccharide, melanin, and monoclonal antibody binding. Infect. Immun. 65, 1836-1841. doi: 10.1128/iai. 65.5.1836-1841.1997

Nosanchuk, J. D., Cleare, W., Franzot, S. P., and Casadevall, A. (1999). Amphotericin B and fluconazole affect cellular charge, macrophage phagocytosis, and cellular morphology of Cryptococcus neoformans at subinhibitory concentrations. Antimicrob. Agents Chemother. 43, 233-239. doi: 10.1128 /aac.43.2.233

Odds, F. C. (2003). Synergy, antagonism, and what the chequerboard puts between them. J. Antimicrob. Chemother. 52:1. doi: 10.1093/jac/dkg301

Olsson, M., Rundquist, I., and Brunk, U. (1987). Flow cytofluorometry of lysosomal acridine orange uptake by living cultured cells. Effect of trypsinization and starvation. Acta Pathol. Microbiol. Immunol. Scand. A 95, 159-165. doi: 10. 1111/j.1699-0463.1987.tb00025_95a.x

Ouyang, H., Bo, T., Zhang, Z., Guo, X., He, M., Li, J., et al. (2018). Ion mobility mass spectrometry with molecular modelling to reveal bioactive isomer conformations and underlying relationship with isomerization. Rapid. Commun. Mass. Spectrom. 32, 1931-1940. doi: 10.1002/rcm.8271

Parveen, M., and Ghalib, R. M. (2012). Flavonoids and antimicrobial activity of leaves of Xylosma longifolium. J. Chilean Chem. Soc. 57, 989-991. doi: 10.1186/ 1472-6882-13-155

Peixoto, L. R., Rosalen, P. L., Ferreira, G. L., Freires, I. A., Carvalho, F. G., Castellano, L. R., et al. (2017). Antifungal activity, mode of action and antibiofilm effects of Laurus nobilis Linnaeus essential oil against Candida spp. Arch. Oral Biol. 73, 179-185. doi: 10.1016/j.archoralbio.2016.10.013
Rajasingham, R., Smith, R. M., Park, B. J., Jarvis, J. N., Govender, N. P., Chiller, T. M., et al. (2017). Global burden of disease of HIV-associated cryptococcal meningitis: an updated analysis. Lancet Infect. Dis. 17, 873-881. doi: 10.1016/ S1473-3099(17)30243-8

Ríos, J. L., and Recio, M. C. (2005). Medicinal plants and antimicrobial activity. J. Ethnopharmacol. 100, 80-84. doi: 10.1016/j.jep.2005. 04.025

Ronot, X., Benel, L., Adolphe, M., and Mounolou, J. C. (1986). Mitochondrial analysis in living cells: the use of rhodamine 123 and flow cytometry. Biol. Cell 57, 1-7. doi: 10.1111/j.1768-322x.1986.tb00458.x

Sant, D. G., Tupe, S. G., Ramana, C. V., and Deshpande, M. V. (2016). Fungal cell membrane-promising drug target for antifungal therapy. J. Appl. Microbiol. 121, 1498-1510. doi: 10.1111/jam.13301

Santos, J. R., Gouveia, L. F., Taylor, E. L., Resende-Stoianoff, M. A., Pianetti, G. A., César, I. C., et al. (2012). Dynamic interaction between fluconazole and amphotericin B against Cryptococcus gattii. Antimicrob. Agents Chemother. 56, 2553-2558. doi: 10.1128/AAC.06098-11

Soares, B. M., Alves, O. A., Ferreira, M. V., Amorim, J. C., Sousa, G. R., Silveira, L. B., et al. (2011). Cryptococcus gattii: in vitro susceptibility to photodynamic inactivation. Photochem. Photobiol. 87, 357-364. doi: 10.1111/j.1751-1097.2010. 00868.x

Thammasit, P., Iadnut, A., Mamoon, K., Khacha-Ananda, S., Chupradit, K., Tayapiwatana, C., et al. (2018). A potential of propolis on major virulence factors of Cryptococcus neoformans. Microb Pathog 123, 296-303. doi: 10.1016/ j.micpath.2018.07.028

Wiederhold, N. P. (2018). The antifungal arsenal: alternative drugs and future targets. Int J Antimicrob. Agents 51, 333-339. doi: 10.1016/j.ijantimicag.2017. 09.002

Zhang, B. B., Wang, D. G., Guo, F. F., and Xuan, C. (2015). Mitochondrial membrane potential and reactive oxygen species in cancer stem cells. Fam. Cancer 14, 19-23. doi: 10.1007/s10689-0149757-9

Zheng, L. F., Dai, F., Zhou, B., Yang, L., and Liu, Z. L. (2008). Prooxidant activity of hydroxycinnamic acids on DNA damage in the presence of $\mathrm{Cu}$ (II) ions: mechanism and structure-activity relationship. Food Chem. Toxicol. 46, 149-156. doi: 10.1016/j.fct.2007.07.010

Conflict of Interest: The authors declare that the research was conducted in the absence of any commercial or financial relationships that could be construed as a potential conflict of interest.

Copyright $\odot 2020$ Folly, Ferreira, Salvador, Sathler, da Silva, Santos, dos Santos, Nunes Neto, Rodrigues, Fernandes, da Silva, de Freitas, Denadai, Rodrigues, Mendonça, Monteiro, Santos, Cabrera, Siless and Lang. This is an open-access article distributed under the terms of the Creative Commons Attribution License (CC BY). The use, distribution or reproduction in other forums is permitted, provided the original author(s) and the copyright owner(s) are credited and that the original publication in this journal is cited, in accordance with accepted academic practice. No use, distribution or reproduction is permitted which does not comply with these terms. 